\title{
Evolutionary Game Analysis on Behavioral Strategies of Multiple Stakeholders in Inclusive Green Growth
}

Ying Qu ( $\square$ quying@dlut.edu.cn )

Dalian University of Technology

\section{Yaodong Cang}

Dalian University of Technology https://orcid.org/0000-0001-7783-4968

\section{Lingling Guo}

Dalian University of Technology

\section{Yue Liu}

Nanjing Forestry University

\section{Research Article}

Keywords: Inclusive green growth, Stakeholders, Evolutionary game, Simulation

Posted Date: September 7th, 2021

DOl: https://doi.org/10.21203/rs.3.rs-741834/v1

License: (c) (i) This work is licensed under a Creative Commons Attribution 4.0 International License. Read Full License 


\section{Evolutionary game analysis on behavioral strategies of multiple}

\section{stakeholders in inclusive green growth}

Ying Qu*, Yaodong Cang, Linging Guo, Yue Liu

School of Economics and Management, Dalian University of Technology, No.2 Ling Gong Road, Dalian City 116024, China

College of Economics and Management, Nanjing Forestry University, No.159 Long Pan Road, Nanjing City 210037, China

\section{First Author, *Corresponding Author:}

Ying Qu, Dalian University of Technology, quying@dlut.edu.cn

\section{Second Author:}

Yaodong Cang, Dalian University of Technology, cangyd1996@163.com

\section{Third Author:}

Lingling Guo, Dalian University of Technology, guolingling@dlut.edu.cn

\section{Forth Author:}

Yue Liu, Nanjing Forestry University, liuyue0901@163.com

Highlights:

As an important initiative to solve severe problems faced by China of environmental degradation and severe income inequality, IGG needs coordination among stakeholders of central government, local government, enterprise and public.

However, the divergence among stakeholders' interest goals hindered them to positively promote IGG.

To understand and balance their interest goals, evolutionary game models were established to analyze and simulate the central supervision and local regulation.

The conditions for all stakeholders to positively promote IGG are analyzed.

The local government should play a leading role in promoting IGG, and the decrease of the economy proportion in the assessment on local government will significantly promote its enthusiasm.

Abstract:

Inclusive green growth has been set as an important initiative to solve the severe problems of environmental degradation and severe income inequality. It requires the joint participation of local government, enterprise and public. However, these stakeholders are not enthusiasm enough as there are divergences among their interest goals. Hence, this paper analyses how to balance the stakeholders' interest goals based on the central supervision and local regulation in environmental protection and income inequity alleviation. Therefore, an evolutionary game model between central and local government, and an evolutionary game model among local government and enterprise and public are conducted. The conclusions are drawn as follows: (1) The local government should play a leading role in promoting IGG, and the decrease of the economy proportion in the assessment on local government will significantly promote its enthusiasm; (2) When the penalty on enterprise increase, both enterprise and the public will choose positive participate behavior faster; (3) The high 
public monitoring cost will hinder both enterprise and public's participation. Finally, some recommendations are put forward.

Key Words: Inclusive green growth; Stakeholders; Evolutionary game; Simulation

\section{Introduction}

Environmental degradation and severe income inequality have become main challenges due to the rapid economic pattern in China. These challenges have brought enormous pressures to the society and restricted the further growth of economy (Liu and Lin, 2019). Currently, the pollution emission in China still seems to be increasing, and the income gap is widening (Dai and Li, 2021). China's carbon emission kept increasing, and the income of the top $10 \%$ has accounted for $40 \%$ social wealth in 2017(Hanewald, Jia, and Liu, 2021). Therefore, there is an urgent need to achieve an effective economic transformation to improve environmental quality and alleviate income inequality (Pan et al., 2019; Sun, Ding, Yang, Yang, and Du, 2020a).

Inclusive green growth (IGG) provides a key theoretical guidance for this economic transformation. As the pathway to achieve sustainable development (World Bank, 2012), IGG is viewed as an economic growth which improves the welfare of current and future generation (Albagoury, 2016). It includes economic growth, income equity, energy conservation and emission reduction (Sun, Ding, Yang, Yang, and Du, 2020b). Inclusive green growth has been set as an important goal for further economic transition in China's $12^{\text {th }}$ Five-Year Plan.

To achieve IGG, Chinese central government has made great effort to promote the participation of stakeholders including local government, enterprise and public: Environment protection and income inequality reduction are incorporated in local government assessment system; Enterprises are encouraged to develop industries promoting green and income inequality alleviation; Besides, the public is encouraged to promote a green lifestyle and purchase green and income equality products. It is noteworthy that, despite repeated central government pledges to promote IGG, there are still unenthusiastic stakeholders unwilling to positively participate in IGG. For example, in 2018, 27 local governments were criticized by central government for inadequate environmental governance, and 8 were criticized for inadequate poverty reduction; Less than $40 \%$ of listed companies disclosed poverty reduction information, and only $24.5 \%$ of listed companies disclosed environmental protection information in 2017; Due to the public's low willingness to buy green products, the sales of green foods in 2019 decreased by 15\% compared to 2014. Therefore, improving the enthusiasm of the above stakeholders to participate has become the key to promote IGG.

However, there are divergence of interest goals hinders their positive participation. Firstly, there are divergence of interest goals between the central and local government. In the central supervision on local government, the central government aims at the economic output, environmental quality, and income equality, and these are also the key indicators for central government to assess local government. While the local governments may tend to maximize the economic output, and improving environmental quality and income equality is usually ignored (Zhang, Xue, and Zhou, 2019). Therefore, how to balance their interest goals by adjusting the assessment for local government plays an important role on promoting the positive participation of local government (Sheng, Zhou, and Zhu, 2020).

Secondly, in the local regulation on enterprise and public, the local government regulates the enterprise to transit into environmental protection and income inequity alleviation, and public to 
develop a green and income inequity alleviation lifestyle, including purchasing green products. However, as the enterprises may aim at improving their economic benefits, they tend to negatively transit because of the transition may cause financial losses to them (Du, Feng, Lu, Kong, and Yang, 2020)(Song, Zhao, and Zeng, 2017). Besides, the public aims at maximizing utility, they may be less motivated in environmental protection and income inequity alleviation if the lifestyle change has brought them excessive financial burden (Cui, Wang, and Wang, 2020). Thus, to promote the participation of enterprise and public, their interest goals should be balanced by local government's regulation (Sun, Wan, Zhang, and Zhou, 2019).

As a consequence, the inconsistent interest goals among these stakeholders have become key practice barriers that hinder their positive participation in IGG in China. Thus, this paper simulates the supervision on local government and the regulation on enterprise and public based on the IGG strategies, and analyzes how to promote these stakeholders to positively participate in IGG based on their interest goals. The main contributions of this study are as follows: (1) Based on the connotation of IGG, the central supervision and the local regulation are analyzed by evolutionary game models of central and local government, local government and enterprise and public, then we investigate the conditions for them to positively participate. (2) With numerical simulations, the dynamic evolutionary directions are discussed.

The structure of this paper is as follows: Section 2 introduces the literature on IGG, central supervision and local regulation, applications of evolutionary game theory and presents the main contributions. Section 3 describes the model of evolutionary game in IGG and the basic assumptions in details. Section 4 presents the simulation results and illustrates the influencing factors. Then based on the results, the conclusions and limitations are given in Section 5.

\section{Literature review}

The previous studies related to this paper mainly demonstrated the connotation, influencing factors of inclusive green growth and the application of evolutionary game theory.

\subsection{Researches on inclusive green growth}

\subsubsection{Connotation of inclusive green growth}

A large number of economic development models were proposed to address the ecological and environmental problems faced by society. Based on the researches on green growth and inclusive growth continues, inclusive green growth was proposed, though the definition and feature of inclusive green growth still remain unsolved.

The United Nations Economic and Social Commission for Asia and the Pacific (UNESCAP) explained the connotation of green growth, believing that "green growth is an environmental sustainable economic process adopted to promote low-carbon development and benefit all members of society"(UNESCAP, 2005). Afterwards, further research were conducted by international organizations like (OECD, 2009) and (WB, 2012), and other scholars. (Meyer, Meyer, and Distelkamp, 2012) defined green growth as an environmental policy strategy that aims at an absolute decoupling between economic growth and resource consumption. (Reilly, 2012) argued that green growth should cover economic growth, reducing environmental impact and job creations.

With continuous attention to issues as poverty and equity, inclusive growth has gradually attracted attention. The World Bank suggested that an inclusive system should be established to provide a wide range of opportunities, without separating growth from equity policies. World Bank (World Bank, 2006) analyzed the issue of inclusive growth in Andhra Pradesh, and pointed out that inclusive 
growth mainly includes agricultural growth, job creation, poverty reduction, and the alleviation of social and regional inequality. (Dev S M, 2007) summarized inclusive growth into three concepts: sustainable and responsible business, social progress and human well-being, and excellent governance.

As shown in the above, though both based on the sustainability of economic growth, green growth focuses more on resources and environment, while inclusive growth focuses more on social fairness. The economy is suggested to be rapid, green and inclusive, and support the poverty for survival and development. (Coughlan S, Lehmann F, and Lehmann J P, 2009) argued that there exists the balance between social benefits and environmental costs, as well as the welfare among generations. (Dhingra $\mathrm{R} \mathrm{M}, 2015$ ) concluded that inclusive green growth is an economic mode with equal opportunities, which is conducive to the access to opportunities, capabilities and security.

\subsubsection{The implement paths of inclusive green growth}

The existing researches on inclusive green growth promotion mostly focus on influencing factors. (Ojha, Pohit, and Ghosh, 2020) employed a recursively dynamic India-specific CGE model, analyzed how to get the balance among greening, growth and inclusiveness. (Xiaoliang and Wulin, 2018) demonstrated that institutional change, technological innovation and capital stock have a significance of improving IGG. (Berkhout et al., 2018) evaluated the effects of the local government on promoting IGG based on the structured research on the previous scholars, and found that the local institutions play an important role on improving social services and public satisfaction.

\subsection{The central supervision and local government regulation}

\subsubsection{The central supervision on local government}

The existing research mainly researched the central supervision in environmental protection, and evaluated its efficiency.

(Xiang and van Gevelt, 2020) investigated the efficiency of central government supervision system by case study method, and the results showed that its effectiveness low at present. (Wang, Sun, and Zhang, 2021) introduced RDD model to evaluate the air improvement effect of the central environmental supervision, and proved that though the environmental supervision improved the air quality, this improvement is not sustainable. Meanwhile, there are also literatures proved that the central supervision has a significant impact on enhancing the local environmental enforcement (Zhang, Chen, and Guo, 2018). (Sun, Wang, Pang, Liu, and Zhang, 2021) analyzed the interaction process in the central environmental supervision system, and the results showed that the central and local government's strategic choices are mainly affected by cost and benefit participating in governance. (Tang et al., 2021) analyzed the impact of the strengthening in environmental protection and cultivated land protection, and found that as the proportion of environmental protection in assessment increased, it has a restraint effect on local governments' illegal land use. (Yu and Wang, 2013) examined the central local conflicts in China's ecological conservation programs, and found that adopting the rewarding strategy is more efficient than penalizing strategy and combination strategy of penalizing and rewarding.

\subsubsection{The local government regulation on enterprise and public}

The existing research mainly focus on how to promote the efficiency of local government regulation. (Yao, Zhang, and Guo, 2020) built a two-tier stochastic frontier analysis model to evaluate the impact of local government and enterprises on actual carbon dioxide emissions reduction, and the results showed that the local governments have a greater influence in carbon dioxide reduction than enterprises, therefore it is of great importance to enhance the participation of enterprises. (Peng, Xie, 
$\mathrm{Ma}$, and $\mathrm{Fu}, 2021$ ) investigated $\mathrm{SO}_{2}$ emissions trading pilot in China, and found that the environmental regulation has a productivity-enhancing effects across all types of industrial enterprises. (Zhou, Qiu, and Wang, 2021) investigated the new Environmental Protection Law, and found that the elimination of unqualified small enterprises has improved the profitability of heavily polluting enterprises. However, there are also literatures analyzed the impact of government regulation on enterprises" productivity, and the results proved that the "win-win" goal between economic output and environmental quality has not been achieved under severe sanctions (Cai and Ye, 2020; Tang, Liu, and Wu, 2020).

There are also literatures emphasized the importance of public's participation on government regulation. (Wang, $\mathrm{Chu}$, and $\mathrm{Gu}, 2021$ ) utilized a spatial durbin model is used to investigate the impact of public attention on wastewater treatment, and the results show that public attention will help improve wastewater treatment by promoting government to enact laws and regulations. (Kolcava, Rudolph, and Bernauer, 2021) established a survey experiment in Switzerland, and found that the environmental regulation with strong transparency and monitoring mechanisms will receive more public support, and a trigger for government intervention should be included. (Liao and Shi, 2018) examined the determinants of green investment in China from the perspective of public appeal, and found that public appeal promotes local governments' enforcement of stricter environmental regulation, thereby encouraging firms to increase their green investment. (Qiao and Yin, 2021) applied an evolutionary game model focusing on the consumers and enterprises' strategies in energy transition, and found that the government incentives may not promote consumer's participation, and the enterprises will choose to transit only when the consumers' participation will bring market prospects and a good social reputation.

\subsection{The applications of evolutionary game theory}

Evolutionary game theory was conducted to analyze the repeated anonymous strategic interactions among stakeholders (D. Friedman, 1991), then guide in the practical dynamic process. The evolutionary game theory has been employed to model the social subject behaviors in economic and management problems (Tian, Govindan, and Qinghua Zhu, 2014). (Wang, Zhao, and Liu, 2020) employed a three-phase dynamic game model, analyzed the social conflicts among government, enterprises and residents in complex disaster management, and found that the governments have to provide larger environmental compensation to the residents' compensation. (Sun and $\mathrm{Li}, 2021$ ) established an evolutionary game model composed of government, logistics enterprise and consumer, analyzed the optimal strategies in recyclable green logistics packaging, and found that the government subsides will promote the logistics enterprises' participation. Based on the perspective of circular industrial chain, (Yunan, Weixin, Yujie, and Hui, 2021) incorporated the government, enterprise and consumers into an evolutionary game model to simulate their interaction in pollution regulation, and the results found out that the price of the resource product affects the consumers' purchase decisions, and in turn affects the enterprises on adopting circular economic mode. (Wang, Li, Cheng, Zhong, and Ma, 2021) developed a comprehensive evolutionary game model among local government, enterprises, and consumer in green technology innovation (GTI), and the results showed that the brand benefits and the economic benefits from consumers' green product consumption are the main factors affecting the GTI system.

\subsection{Summary}

In summary, the importance of local government, enterprise and public's participation to central supervision and local regulation was emphasized in the literature, while there are few research gaps: 
Firstly, the existing research about IGG has studied the characteristic of IGG and its driving factors, while few studies analyzed how to promote the stakeholders' participation in IGG. Secondly, in the existing research about central supervision and local regulation, most of the literatures focused on the regulation on environmental protection, and ignored the regulation on income inequity alleviation. Besides, the impact of local regulation on enterprises' participation remains unclear. Thirdly, the role of public is mainly set as consumer, few studies considered its role as a monitor. Thus, to analyze the central supervision and local regulation in environmental protection and income inequity alleviation, this paper constructs a central and local and a local government and enterprise and public evolutionary game model, to explore how to promote these stakeholders to positively participate in IGG.

\section{The formulation of model and method}

This research employs evolutionary game model to analyze the interest conflicts among stakeholders. The evolutionary game theory was first applied to the analysis of game behavior among animals (Smith, 1974). And a number of studies have constructed evolutionary models to demonstrate the cooperative strategies (Fang et al., 2019; Xu, Zhang, and Shi, 2019). In line with the requirements of stakeholders in IGG and evolutionary game theory, the following models and assumptions are established.

\subsection{Model descriptions and assumptions}

The stakeholders' game strategies are as follows:

The central government, supervises and assesses the local government from the economic output, environmental protection and income inequality reduction, may choose the positive supervision (PS) and negative supervision (NS). When choosing the positive supervision behavior, the central government severely supervises local government, and punishes it for its negative participation in IGG to promote the local government's willingness on inclusive green growth. And the negative supervision means the central government loosens the supervision over local government. Let $\mathrm{w}$ represent the probability of the central government choosing positive supervision, while the probability of choosing negative supervision is $1-\mathrm{w}$.

The local government is also an important regulator in inclusive green growth, its strategies including positive regulation (PR) and negative regulation (NR). Positive regulation means that the local government strictly promotes the inclusive green behavior of the enterprise and public, severely cracks down on the enterprise's negative behaviors, therefore it may promote enterprises and the public to implement inclusive green behaviors. The economic output may be hindered when promoting the environmental quality and income inequity reduction. Negative regulation means that the government does not supervise any behavior of enterprise. If the probability of local government choosing positive regulate is $\mathrm{x}$, then $1-\mathrm{x}$ is the probability of choosing negative regulate.

The enterprise is another important stakeholder in inclusive green growth, has two kinds of game strategies, which are positive implementation (PI) and negative implementation (NI). Positive implementation represents that enterprise produces green, income inequity alleviation products and increase social security expenditure. Positive implementation may significantly improve the environmental quality and reduce the income gap. Although positive implementation behavior promotes the environmental protection and income inequity reduction, it also brings cost burden to the enterprises. Negative implementation represents that enterprise produces regular products and the public gets less social security. Hence, subsidies for positive implementation are needed to compensate enterprises. If the probability of the enterprise choosing positive implement is $\mathrm{y}$, then 
$1-y$ is the probability of choosing negative implement.

The public's behavioral strategies support the development of inclusive green growth. Public can choose participation behavior (PB) and non- participation behavior (NB). The positive participation behavior indicates that the public monitors the inclusive green effort of enterprise and local government, and also buys green and income inequity alleviation products. The non- participation behavior indicates the public buys regular products without monitoring. If the probability of the public choosing participation behavior is $\mathrm{z}$, then $1-\mathrm{z}$ is the probability of choosing non- participation behavior.

The interactions among the stakeholders are shown in Fig 1.

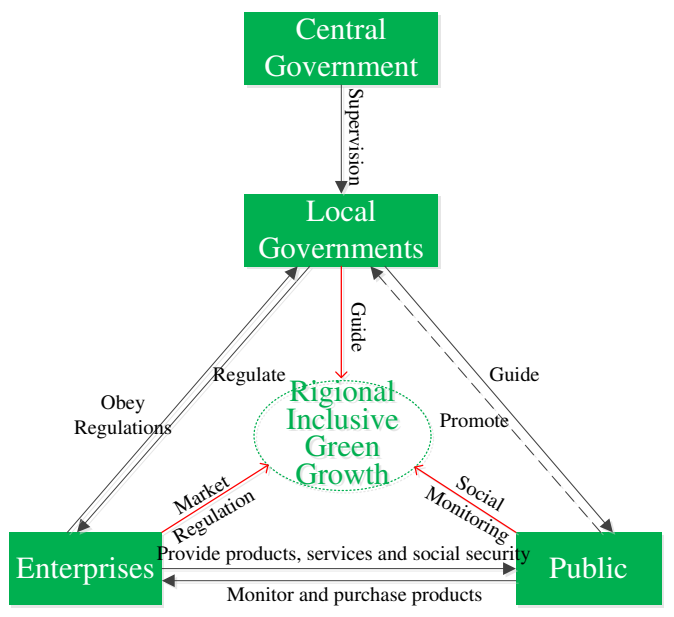

Fig 1 The interaction among stakeholders in IGG

\subsection{The parameters of the models}

To further test the above hypothesis, parameters about the stakeholders are set as follows:

(1) The parameters related to governments

$C_{C}$ represents the central government's positive supervision cost; $\theta_{\mathrm{g}}, \theta_{\mathrm{i}}$ and $\theta_{\mathrm{e}}$ are the importance coefficients for local green degree, inclusive degree and economy degree. $F_{L}$ represents the penalization for the negative regulation of local government when the central government positively supervises. $\mathrm{R}_{\mathrm{L}}$ indicates the social welfare such as environmental improvement and income gap reduction.

$C_{L}$ expresses the local government's cost for positive regulation. $\gamma_{g}, \gamma_{i}$ and $\gamma_{e}$ mean the proportion coefficients of green degree, inclusive degree and economy degree in the assessment by central government. The local government imposes the reward $\mathrm{M}_{1}, \mathrm{M}_{2}$ to the public in the positive and negative strategies, respectively. Thus, there exists $\mathrm{M}_{1}>\mathrm{M}_{2}$. If the enterprise chooses positive implementation, the local government gains a social benefit $\mathrm{B}_{\mathrm{L}}$. And the public credit for local government's positive regulation is denoted by $\mathrm{E}_{\mathrm{L}}$.

(2) The parameters related to enterprise

The regulation cost and benefit of enterprise's positive implementation is denoted by $C_{E}$ and $B_{E}$, such as insurance paid to employees and the public franchise, thus, the public gets benefit as Ep. The local government and enterprise loss a social reputation $\mathrm{N}$ when enterprise chooses negative strategy. $R_{E}$ is the improvement of the enterprise's credibility when the public positively participates. The penalty for negative behavior of enterprise is denoted by $\mathrm{F}_{\mathrm{E}}$. The price and sales volume of products under enterprise' inclusive behavior and traditional behavior are expressed as $\mathrm{P}_{\mathrm{i}}, \mathrm{Q}_{\mathrm{i}}, \mathrm{P}_{\mathrm{N}}$ 
and $\mathrm{Q}_{\mathrm{N}}$.

(3) The parameters related to public

As the implementer and monitor of inclusive green behavior, the public pays participation cost $C_{P}$ and monitor cost $\mathrm{C}_{\mathrm{S}}$.

Based on the above assumptions, under different choices of behavioral strategies, the payoff matrix is shown as in Table 1 and Table 2.

Table 1 The Payoff Matrix of Evolutionary Game Model between central and local government

\begin{tabular}{lccc}
\hline & & \multicolumn{2}{c}{ Local Government } \\
\cline { 3 - 4 } & & $\mathrm{PR}(\mathrm{x})$ & $\mathrm{NR}(1-\mathrm{x})$ \\
\hline \multirow{4}{*}{ Central Government } & $\mathrm{PS}(\mathrm{w})$ & $-\mathrm{C}_{\mathrm{C}}+\left(\theta_{\mathrm{g}}+\theta_{\mathrm{i}}\right) * \mathrm{R}_{\mathrm{L}}-\theta_{\mathrm{e}} * \mathrm{~L}_{\mathrm{L}}$ & $-\mathrm{C}_{\mathrm{C}}+\mathrm{F}_{\mathrm{L}}$ \\
& & $-\mathrm{C}_{\mathrm{L}}+\left(\gamma_{\mathrm{g}}+\gamma_{\mathrm{i}}\right) * \mathrm{R}_{\mathrm{L}}-\gamma_{\mathrm{e}}{ }^{*} \mathrm{~L}_{\mathrm{L}}$ & $-\mathrm{F}_{\mathrm{L}}$ \\
& $\mathrm{NS}(1-\mathrm{w})$ & $\left(\theta_{\mathrm{g}}+\theta_{\mathrm{i}}\right) * \mathrm{R}_{\mathrm{L}}-\theta{ }^{*} \mathrm{~L}_{\mathrm{L}}$ & 0 \\
& & $-\mathrm{C}_{\mathrm{L}}+\left(\gamma_{\mathrm{g}}+\gamma_{\mathrm{i}}\right) * \mathrm{R}_{\mathrm{L}}-\gamma_{\mathrm{e}} \mathrm{L}_{\mathrm{L}}$ & 0 \\
\hline
\end{tabular}

Table 2 The Payoff Matrix of Evolutionary Game Model among local government, enterprise and public

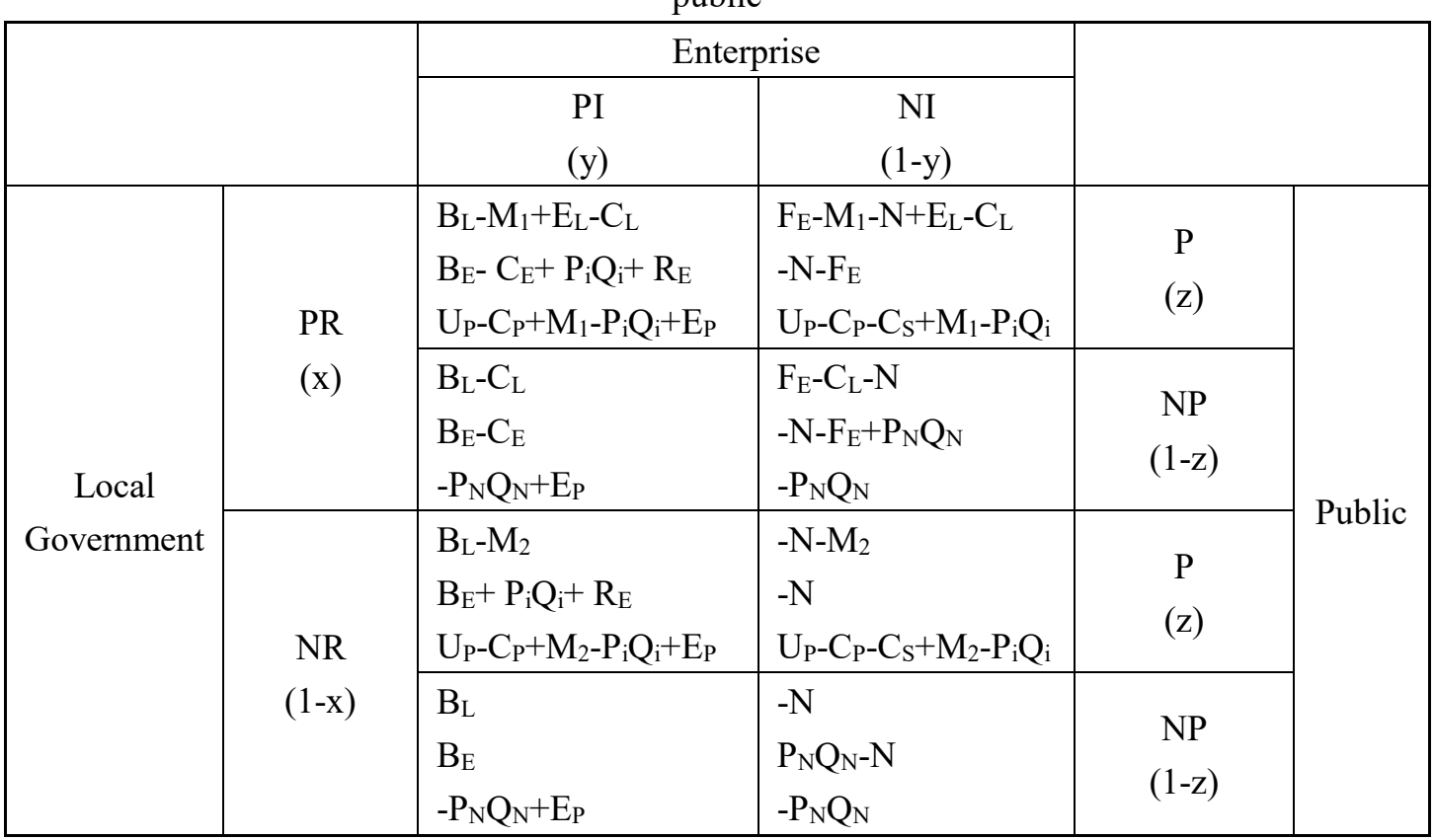

3.3 Stability analysis of central government and local government model

As shown in Table 1, the expected revenues of the governments choosing positive and negative strategies can be calculated respectively.

The expected revenues of the central government choosing positive strategy $\mathrm{E}_{11}$ and positive strategy $\mathrm{E}_{12}$ :

$\mathrm{E}_{11}=\mathrm{x} *\left[-\mathrm{C}_{\mathrm{C}}+\left(\theta_{\mathrm{g}}+\theta_{\mathrm{i}}\right) * \mathrm{R}_{\mathrm{L}}-\theta_{\mathrm{e}} * \mathrm{~L}_{\mathrm{L}}\right]+(1-\mathrm{x}) *\left(-\mathrm{C}_{\mathrm{C}}+\mathrm{F}_{\mathrm{L}}\right)$

$\mathrm{E}_{12}=\mathrm{x} *\left[\left(\theta_{\mathrm{g}}+\theta_{\mathrm{i}}\right) * \mathrm{R}_{\mathrm{L}}-\theta_{\mathrm{e}} * \mathrm{~L}_{\mathrm{L}}\right]$

The expected revenues of the local government choosing positive strategy $\mathrm{E}_{21}$ and positive strategy $\mathrm{E}_{22}$ :

$\mathrm{E}_{21}=\mathrm{w} *\left[-\mathrm{C}_{\mathrm{L}}+\left(\gamma_{\mathrm{g}}+\gamma_{\mathrm{i}}\right) * \mathrm{R}_{\mathrm{L}}-\gamma_{\mathrm{e}} * \mathrm{~L}_{\mathrm{L}}\right]+(1-\mathrm{w}) *\left[-\mathrm{C}_{\mathrm{L}}+\left(\gamma_{\mathrm{g}}+\gamma_{\mathrm{i}}\right) * \mathrm{R}_{\mathrm{L}}-\gamma_{\mathrm{e}} * \mathrm{~L}_{\mathrm{L}}\right]$

$\mathrm{E}_{21}=-\mathrm{w}^{*} \mathrm{~F}_{\mathrm{L}}$ 
Then the replicator dynamic equation of the governments' strategies as follows:

$\mathrm{F}(\mathrm{w})=\mathrm{dw} / \mathrm{dt}=\mathrm{w} *(1-\mathrm{w}) *\left(\mathrm{E}_{11}-\mathrm{E}_{12}\right)=\mathrm{w} *(1-\mathrm{w}) *\left(\mathrm{~F}_{\mathrm{L}}-\mathrm{C}_{\mathrm{C}}-\mathrm{F}_{\mathrm{L}} * \mathrm{x}\right)$

$\mathrm{F}(\mathrm{x})=\mathrm{dx} / \mathrm{dt}=\mathrm{x} *(1-\mathrm{x}) *\left(\mathrm{E}_{21}-\mathrm{E}_{22}\right)=\mathrm{x} *(1-\mathrm{x}) *\left[\mathrm{~F}_{\mathrm{L}} * \mathrm{w}+\mathrm{R}_{\mathrm{L}} *\left(\gamma_{\mathrm{g}}+\gamma_{\mathrm{i}}\right)-\mathrm{L}_{\mathrm{L}} * \gamma_{\mathrm{e}}-\mathrm{C}_{\mathrm{L}}\right]$

Let $\mathrm{F}(\mathrm{w})=0, \mathrm{~F}(\mathrm{x})=0$, we can obtain 4 pure strategy solutions, which are $(0,0),(0,1),(1,0)$ and $(1,1)$. $\{(\mathrm{w}, \mathrm{x}) \mid 0 \leqslant \mathrm{~W} \leqslant 1 ; 0 \leqslant \mathrm{x} \leqslant 1\}$.

To further investigate the dynamic equilibrium point of the system, stability analysis of four equilibrium points is made. When $x=\frac{F_{L}-C_{C}}{F_{L}}$, there is $F(w) \equiv 0$. In this case, the central government's strategy will keep unchanged. When $\mathrm{x}<\frac{\mathrm{F}_{\mathrm{L}}-\mathrm{C}_{\mathrm{C}}}{\mathrm{F}_{\mathrm{L}}}$, there exist $\left.\mathrm{F}^{\prime}(\mathrm{w})\right|_{\mathrm{w}=1}<0$ and $\left.\mathrm{F}^{\prime}(\mathrm{w})\right|_{\mathrm{w}=0}>0$, so $\mathrm{w}=1$ becomes the equilibrium in the system, and the central government's strategic behavior is to impose negative supervision. And when $\mathrm{x}>\frac{\mathrm{F}_{\mathrm{L}}-\mathrm{C}_{\mathrm{C}}}{\mathrm{F}_{\mathrm{L}}}, \mathrm{w}=0$ become the equilibrium point, then the strategic choice of the central government is to impose positive supervision.

When $\mathrm{w}=\frac{\mathrm{L}_{\mathrm{L}}{ }^{*} \gamma_{\mathrm{e}}+\mathrm{C}_{\mathrm{L}}-\mathrm{R}_{\mathrm{L}} *\left(\gamma_{\mathrm{g}}+\gamma_{\mathrm{i}}\right)}{\mathrm{F}_{\mathrm{L}}}$, there is $\mathrm{F}(\mathrm{x}) \equiv 0$. At this time, local government's strategic behavior remains whatever the value of $\mathrm{w}$ takes. When $\mathrm{w}<\frac{\mathrm{L}_{\mathrm{L}}{ }^{*} \gamma_{\mathrm{e}}+\mathrm{C}_{\mathrm{L}}-\mathrm{R}_{\mathrm{L}}{ }^{*}\left(\gamma_{\mathrm{g}}+\gamma_{\mathrm{i}}\right)}{\mathrm{F}_{\mathrm{L}}}$, there are $\left.\mathrm{F}^{\prime}(\mathrm{x})\right|_{\mathrm{x}=1}>0$ and $\left.\mathrm{F}^{\prime}(\mathrm{x})\right|_{\mathrm{x}=0}<0, \mathrm{x}=0$ is the equilibrium point of evolution, and the behavior of the local government is to carry out negative supervision. When $\mathrm{w}>\frac{\mathrm{L}_{\mathrm{L}}{ }^{*} \gamma_{\mathrm{e}}+\mathrm{C}_{\mathrm{L}}-\mathrm{R}_{\mathrm{L}} *\left(\gamma_{\mathrm{g}}+\gamma_{\mathrm{i}}\right)}{\mathrm{F}_{\mathrm{L}}}, \mathrm{x}=1$ is the equilibrium point of evolution, and the local government will choose positive strategy.

According to the above analysis, when the supervision cost reduces and penalty for local governments increases, the central government is encouraged to positive supervise. By enhancing the importance of inclusive and green degree in the assessment and increasing the penalty, $\mathrm{x}$ can move toward 1 .

Thus, the Jacobian matrix $\mathrm{J}_{1}$ is obtained from the first partial derivative of the replicator dynamic equations.

$$
\mathrm{J}_{1}=\left[\begin{array}{cc}
\partial \mathrm{F}(\mathrm{w}) / \partial \mathrm{w} & \partial \mathrm{F}(\mathrm{w}) / \partial \mathrm{x} \\
\partial \mathrm{F}(\mathrm{x}) / \partial \mathrm{w} & \partial \mathrm{F}(\mathrm{x}) / \partial \mathrm{x}
\end{array}\right]
$$

As shown in Table 3, four equilibrium points (pure strategy solutions) are introduced into Jacobian matrix, then the plus or minus characteristics of det $J_{1}$ and $\operatorname{tr} J_{1}$ are judged, if det $J_{1}>0$, and $\operatorname{tr} J_{1}<0$, the equilibrium point becomes evolutionary stability strategy (ESS). Thus, there are three possible game equilibrium points for central-local government in inclusive green growth. First, there is an equilibrium point $(0,0)$ when $\mathrm{R}_{\mathrm{L}} *\left(\gamma_{\mathrm{g}}+\gamma_{\mathrm{i}}\right)<\mathrm{L}_{\mathrm{L}} * \gamma_{\mathrm{e}}+\mathrm{C}_{\mathrm{L}}$ and $\mathrm{C}_{\mathrm{C}}>\mathrm{F}_{\mathrm{L}}$. That is, at this equilibrium point, if the central government lacks enough penalty on negative local government, and emphasis on economy output in assessment, the governments would both choose the strategy of "negative supervision".

There is second equilibrium point $(0,1)$ when $R_{L} *\left(\gamma_{g}+\gamma_{i}\right)>L_{L} * \gamma_{e}+C_{L}$. As can been seen that increase the proportion of inclusiveness and green degree in assessment, central government will choose negative strategy while local government will positive regulate. If $\mathrm{C}_{\mathrm{C}}-\mathrm{F}_{\mathrm{L}}<0, \mathrm{C}_{\mathrm{L}}-\mathrm{F}_{\mathrm{L}}+\mathrm{L}_{\mathrm{L}} * \gamma_{\mathrm{e}}-\mathrm{R}_{\mathrm{L}} *\left(\gamma_{\mathrm{g}}+\gamma_{\mathrm{i}}\right)>0$, there is the last equilibrium point $(1,0)$. In this equilibrium point, the penalty on local government gives central government an incentive to positively supervise, 
but cannot promote the local government to positively regulate.

Table 3 Equilibrium Points between the governments

\begin{tabular}{|c|c|c|}
\hline $\begin{array}{l}\text { Equilibrium } \\
\text { Points }\end{array}$ & $\operatorname{det} \mathrm{J}_{1}$ and $\operatorname{tr} \mathrm{J}_{1}$ & Condition \\
\hline$(0,0)$ & $\begin{array}{c}{\left[\mathrm{C}_{\mathrm{L}}+\mathrm{L}_{\mathrm{L}} * \gamma_{\mathrm{e}}-\mathrm{R}_{\mathrm{L}} *\left(\gamma_{\mathrm{g}}+\gamma_{\mathrm{i}}\right)\right]\left(\mathrm{C}_{\mathrm{C}}-\mathrm{F}_{\mathrm{L}}\right)} \\
\left(\mathrm{F}_{\mathrm{L}}-\mathrm{C}_{\mathrm{C}}\right)-\mathrm{C}_{\mathrm{L}}-\mathrm{L}_{\mathrm{L}} * \gamma_{\mathrm{e}}+\mathrm{R}_{\mathrm{L}} *\left(\gamma_{\mathrm{g}}+\gamma_{\mathrm{i}}\right)\end{array}$ & $\begin{array}{c}\mathrm{C}_{\mathrm{L}}+\mathrm{L}_{\mathrm{L}} * \gamma_{\mathrm{e}}>\mathrm{R}_{\mathrm{L}} *\left(\gamma_{\mathrm{g}}+\gamma_{\mathrm{i}}\right) \\
\mathrm{C}_{\mathrm{C}}>\mathrm{F}_{\mathrm{L}}\end{array}$ \\
\hline$(0,1)$ & $\begin{array}{c}-\left[\mathrm{C}_{\mathrm{L}}+\mathrm{L}_{\mathrm{L}} * \gamma_{\mathrm{e}}-\mathrm{R}_{\mathrm{L}} *\left(\gamma_{\mathrm{g}}+\gamma_{\mathrm{i}}\right)\right] \mathrm{C}_{\mathrm{C}} \\
\mathrm{C}_{\mathrm{L}}+\mathrm{L}_{\mathrm{L}} * \gamma_{\mathrm{e}}-\mathrm{R}_{\mathrm{L}} *\left(\gamma_{\mathrm{g}}+\gamma_{\mathrm{i}}\right)-\mathrm{C}_{\mathrm{C}}\end{array}$ & $\mathrm{C}_{\mathrm{L}}+\mathrm{L}_{\mathrm{L}} * \gamma_{\mathrm{e}}<\mathrm{R}_{\mathrm{L}} *\left(\gamma_{\mathrm{g}}+\gamma_{\mathrm{i}}\right)$ \\
\hline$(1,0)$ & $\begin{array}{c}-\left(\mathrm{C}_{\mathrm{C}}-\mathrm{F}_{\mathrm{L}}\right)\left[\mathrm{C}_{\mathrm{L}}-\mathrm{F}_{\mathrm{L}}+\mathrm{L}_{\mathrm{L}} * \gamma_{\mathrm{e}}-\mathrm{R}_{\mathrm{L}} *\left(\gamma_{\mathrm{g}}+\gamma_{\mathrm{i}}\right)\right] \\
\mathrm{C}_{\mathrm{C}}-\mathrm{C}_{\mathrm{L}}-\mathrm{L}_{\mathrm{L}} * \gamma_{\mathrm{e}}+\mathrm{R}_{\mathrm{L}} *\left(\gamma_{\mathrm{g}}+\gamma_{\mathrm{i}}\right)\end{array}$ & $\begin{array}{c}\mathrm{C}_{\mathrm{C}}<\mathrm{F}_{\mathrm{L}} \\
\mathrm{C}_{\mathrm{L}}+\mathrm{L}_{\mathrm{L}} * \gamma_{\mathrm{e}}>\mathrm{R}_{\mathrm{L}} *\left(\gamma_{\mathrm{g}}+\gamma_{\mathrm{i}}\right)+\mathrm{F}_{\mathrm{L}}\end{array}$ \\
\hline$(1,1)$ & $\begin{array}{l}{\left[\mathrm{C}_{\mathrm{L}}-\mathrm{F}_{\mathrm{L}}+\mathrm{L}_{\mathrm{L}} * \gamma_{\mathrm{e}}-\mathrm{R}_{\mathrm{L}} *\left(\gamma_{\mathrm{g}}+\gamma_{\mathrm{i}}\right)\right] \mathrm{C}_{\mathrm{C}}} \\
\mathrm{C}_{\mathrm{L}}-\mathrm{F}_{\mathrm{L}}+\mathrm{L}_{\mathrm{L}} * \gamma_{\mathrm{e}}-\mathrm{R}_{\mathrm{L}} *\left(\gamma_{\mathrm{g}}+\gamma_{\mathrm{i}}\right)+\mathrm{C}_{\mathrm{C}} \\
\end{array}$ & (r) \\
\hline
\end{tabular}

3.4 Stability analysis of local government and enterprise and public model

According to the above assumptions, the tripartite game among local government, enterprise and the public under different behavior strategic choices is shown as in Table 2. Then the expected revenues of the local government choosing positive regulate and negative regulate strategies can be calculated, denoted by $\mathrm{E}_{31}, \mathrm{E}_{32}$ respectively.

$\mathrm{E}_{31}=\mathrm{yz}\left(\mathrm{B}_{\mathrm{L}}-\mathrm{M}_{1}+\mathrm{E}_{\mathrm{L}}-\mathrm{C}_{\mathrm{L}}\right)+\mathrm{z}(1-\mathrm{y})\left(\mathrm{F}_{\mathrm{E}}-\mathrm{M}_{1}-\mathrm{N}+\mathrm{E}_{\mathrm{L}}-\mathrm{C}_{\mathrm{L}}\right)+\mathrm{y}(1-\mathrm{z})\left(\mathrm{B}_{\mathrm{L}}-\mathrm{C}_{\mathrm{L}}\right)$

$+(1-\mathrm{y})(1-\mathrm{z})\left(\mathrm{F}_{\mathrm{E}}-\mathrm{C}_{\mathrm{L}}-\mathrm{N}\right)$

$E_{32}=y z\left(B_{L}-M_{2}\right)+z(1-y)\left(-N-M_{2}\right)+y(1-z) B_{L}+(1-y)(1-z)(-N)$

The expected revenues of enterprise choosing positive implement and negative implement strategies, denoted by $\mathrm{E}_{41}, \mathrm{E}_{42}$ :

$\mathrm{E}_{41}=\mathrm{xz}\left(\mathrm{B}_{\mathrm{E}}-\mathrm{C}_{\mathrm{E}}+\mathrm{P}_{\mathrm{i}} \mathrm{Q}_{\mathrm{i}}+\mathrm{R}_{\mathrm{E}}\right)+\mathrm{x}(1-\mathrm{z})\left(\mathrm{B}_{\mathrm{E}}-\mathrm{C}_{\mathrm{E}}\right)+\mathrm{z}(1-\mathrm{x})\left(\mathrm{B}_{\mathrm{E}}+\mathrm{P}_{\mathrm{i}} \mathrm{Q}_{\mathrm{i}}+\mathrm{R}_{\mathrm{E}}\right)$

$+(1-\mathrm{z})(1-\mathrm{x})\left(\mathrm{P}_{\mathrm{N}} \mathrm{Q}_{\mathrm{N}}-\mathrm{N}\right)$

$\mathrm{E}_{42}=\mathrm{xz}\left(-\mathrm{N}-\mathrm{F}_{\mathrm{E}}\right)+\mathrm{x}(1-\mathrm{z})\left(-\mathrm{N}-\mathrm{F}_{\mathrm{E}}+\mathrm{P}_{\mathrm{N}} \mathrm{Q}_{\mathrm{N}}\right)+\mathrm{z}(1-\mathrm{x})(-\mathrm{N})$

$+(1-\mathrm{z})(1-\mathrm{x})\left(\mathrm{P}_{\mathrm{N}} \mathrm{Q}_{\mathrm{N}}-\mathrm{N}\right)$

The expected revenues of public choosing participate behavior and non-participate behavior strategies, denoted by $\mathrm{E}_{51}, \mathrm{E}_{52}$ :

$366 \mathrm{E}_{51}=\mathrm{xy}\left(\mathrm{U}_{\mathrm{P}}-\mathrm{C}_{\mathrm{P}}+\mathrm{M}_{1}-\mathrm{P}_{\mathrm{i}} \mathrm{Q}_{\mathrm{i}}+\mathrm{E}_{\mathrm{P}}\right)+\mathrm{x}(1-\mathrm{y})\left(\mathrm{U}_{\mathrm{P}}-\mathrm{C}_{\mathrm{P}}-\mathrm{C}_{\mathrm{S}}+\mathrm{M}_{1}-\mathrm{P}_{\mathrm{i}} \mathrm{Q}_{\mathrm{i}}\right)$

$+\mathrm{y}(1-\mathrm{x})\left(\mathrm{U}_{\mathrm{P}}-\mathrm{C}_{\mathrm{P}}+\mathrm{M}_{2}-\mathrm{P}_{\mathrm{i}} \mathrm{Q}_{\mathrm{i}}+\mathrm{E}_{\mathrm{p}}\right)+(1-\mathrm{y})(1-\mathrm{x})\left(\mathrm{U}_{\mathrm{P}}-\mathrm{C}_{\mathrm{P}}-\mathrm{C}_{\mathrm{S}}+\mathrm{M}_{2}-\mathrm{P}_{\mathrm{i}} \mathrm{Q}_{\mathrm{i}}\right)$

$\mathrm{E}_{52}=\mathrm{y}\left(-\mathrm{P}_{\mathrm{N}} \mathrm{Q}_{\mathrm{N}}+\mathrm{E}_{\mathrm{P}}\right)+(1-\mathrm{y})\left(-\mathrm{P}_{\mathrm{N}} \mathrm{Q}_{\mathrm{N}}\right)$

368 Thus, the replicator dynamic equation of the government, enterprise and public can be set as follows:

$369 \quad \mathrm{~F}(\mathrm{x})=\mathrm{dx} / \mathrm{dt}=\mathrm{x}(1-\mathrm{x})\left(\mathrm{E}_{31}-\mathrm{E}_{32}\right)$

$=\mathrm{x}(1-\mathrm{x})\left(\mathrm{F}_{\mathrm{E}}-\mathrm{C}_{\mathrm{L}}-\mathrm{F}_{\mathrm{E}} * \mathrm{y}+\mathrm{E}_{\mathrm{L}} * \mathrm{z}-\mathrm{M}_{1} * \mathrm{z}+\mathrm{M}_{2} * \mathrm{z}\right)$

$\mathrm{F}(\mathrm{y})=\mathrm{dy} / \mathrm{dt}=\mathrm{y}(1-\mathrm{y})\left(\mathrm{E}_{41}-\mathrm{E}_{42}\right)$

$=y(1-y)\left(B_{E}-P_{N} Q_{N}-C_{E} * x+F_{E} * x+N+R_{E} * z+P_{N} Q_{N}+P_{i} Q_{i} * z\right)$

$\mathrm{F}(\mathrm{z})=\mathrm{dz} / \mathrm{dt}=\mathrm{z}(1-\mathrm{z})\left(\mathrm{E}_{51}-\mathrm{E}_{52}\right)$

$=\mathrm{z}(1-\mathrm{z})\left(\mathrm{C}_{\mathrm{P}}+\mathrm{C}_{\mathrm{S}}-\mathrm{M}_{2}-\mathrm{U}_{\mathrm{P}}-\mathrm{P}_{\mathrm{N}} \mathrm{Q}_{\mathrm{N}}+\mathrm{P}_{\mathrm{i}} \mathrm{Q}_{\mathrm{i}}-\mathrm{C}_{\mathrm{S}} * \mathrm{y}-\mathrm{M}_{1} * \mathrm{x}+\mathrm{M}_{2} * \mathrm{x}\right)$

When $\mathrm{z}=\frac{\mathrm{yF_{E }}+\mathrm{C}_{\mathrm{L}}-\mathrm{F}_{\mathrm{E}}}{\mathrm{E}_{\mathrm{L}}-\mathrm{M}_{1}+\mathrm{M}_{2}}$, there is $\mathrm{F}(\mathrm{x}) \equiv 0$, at this time, the behavior strategy of local government remains 
unchanged. When $z>\frac{y F_{E}+C_{L}-F_{E}}{E_{L}-M_{1}+M_{2}}$, there are $\left.F^{\prime}(x)\right|_{x=1}<0$ and $\left.F^{\prime}(x)\right|_{x=0}>0$, that means $x=1$ becomes the equilibrium point in the evolutionary system, and the local government's strategic behavior is positive regulate. When $\mathrm{z}<\frac{\mathrm{yF_{ \textrm {E } } + C _ { \mathrm { L } } - \mathrm { F } _ { \mathrm { E } }}}{\mathrm{E}_{\mathrm{L}}-\mathrm{M}_{1}+\mathrm{M}_{2}}$, there exist $\left.\mathrm{F}^{\prime}(\mathrm{x})\right|_{\mathrm{x}=1}>0$ and $\left.\mathrm{F}^{\prime}(\mathrm{x})\right|_{\mathrm{x}=0}<0$, so $\mathrm{x}=0$ becomes the equilibrium point of evolution, and the strategic choice of the local government is to impose positive regulation.

When $z=\frac{P_{N} Q_{N}+\left(C_{E}-F_{E}\right) x-B_{E}-N}{R_{E}+P_{N} Q_{N}+P_{i} Q_{i}}$, there is $F(y) \equiv 0$, at this time, the enterprise's behavioral strategy keeps unchanged no matter what value y takes. When $z>\frac{\mathrm{P}_{\mathrm{N}} \mathrm{Q}_{\mathrm{N}}+\left(\mathrm{C}_{\mathrm{E}}-\mathrm{F}_{\mathrm{E}}\right) \mathrm{x}-\mathrm{B}_{\mathrm{E}}-\mathrm{N}}{\mathrm{R}_{\mathrm{E}}+\mathrm{P}_{\mathrm{N}} \mathrm{Q}_{\mathrm{N}}+\mathrm{P}_{\mathrm{i}} \mathrm{Q}_{\mathrm{i}}}$, there are $\left.\mathrm{F}^{\prime}(\mathrm{y})\right|_{\mathrm{y}=1}<0$ and $\left.\mathrm{F}^{\prime}(\mathrm{y})\right|_{\mathrm{y}=0}>0$, then $\mathrm{y}=1$ becomes the equilibrium point of evolution, and the behavioral strategy of the enterprise is to positive implement. When $z<\frac{\mathrm{P}_{\mathrm{N}} \mathrm{Q}_{\mathrm{N}}+\left(\mathrm{C}_{\mathrm{E}}-\mathrm{F}_{\mathrm{E}}\right) \mathrm{x}-\mathrm{B}_{\mathrm{E}}-\mathrm{N}}{\mathrm{R}_{\mathrm{E}}+\mathrm{P}_{\mathrm{N}} \mathrm{Q}_{\mathrm{N}}+\mathrm{P}_{\mathrm{i}} \mathrm{Q}_{\mathrm{i}}}$, there are $\left.\mathrm{F}^{\prime}(\mathrm{y})\right|_{\mathrm{y}=1}>0$ and $\left.\mathrm{F}^{\prime}(\mathrm{y})\right|_{\mathrm{y}=0}<0$, so $\mathrm{y}=0$ is the evolution equilibrium point, then the enterprise's strategy choice turns to negative implement.

When $\mathrm{x}=\frac{\mathrm{C}_{\mathrm{P}}+\mathrm{C}_{\mathrm{S}}-\mathrm{M}_{2}-\mathrm{U}_{\mathrm{P}}-\mathrm{P}_{\mathrm{N}} \mathrm{Q}_{\mathrm{N}}+\mathrm{P}_{\mathrm{i}} \mathrm{Q}_{\mathrm{i}}-\mathrm{y} \mathrm{C}_{\mathrm{S}}}{\mathrm{M}_{1}-\mathrm{M}_{2}}$, there is $\mathrm{F}(\mathrm{z}) \equiv 0$, at this time, the public's policy choice remains. When $\mathrm{x}>\frac{\mathrm{C}_{\mathrm{P}}+\mathrm{C}_{\mathrm{S}}-\mathrm{M}_{2}-\mathrm{U}_{\mathrm{p}}-\mathrm{P}_{\mathrm{N}} \mathrm{Q}_{\mathrm{N}}+\mathrm{P}_{\mathrm{i}} \mathrm{Q}_{\mathrm{i}}-\mathrm{y} \mathrm{C}_{\mathrm{S}}}{\mathrm{M}_{1}-\mathrm{M}_{2}}$, there are $\left.\mathrm{F}^{\prime}(\mathrm{z})\right|_{\mathrm{z}=1}<0$ and $\left.\mathrm{F}^{\prime}(\mathrm{z})\right|_{\mathrm{z}=0}>0$, so $\mathrm{z}=1$ is the evolution equilibrium point, and the strategic choice of the public is to participate. When $\mathrm{x}<\frac{\mathrm{C}_{\mathrm{P}}+\mathrm{C}_{\mathrm{S}}-\mathrm{M}_{2}-\mathrm{U}_{\mathrm{P}}-\mathrm{P}_{\mathrm{N}} \mathrm{Q}_{\mathrm{N}}+\mathrm{P}_{\mathrm{i}} \mathrm{Q}_{\mathrm{i}}-\mathrm{y} \mathrm{C}_{\mathrm{S}}}{\mathrm{M}_{\mathrm{1}}-\mathrm{M}_{2}}$, there are $\left.\mathrm{F}^{\prime}(\mathrm{z})\right|_{\mathrm{z}=1}>0$ and $\left.\mathrm{F}^{\prime}(\mathrm{z})\right|_{\mathrm{z}=0}<0$, so $\mathrm{z}=0$ is the evolution equilibrium point, and the public's strategic choice is not to participate.

From the above analysis, as the penalty on enterprise decreases and subsidies to the public increase, when the enterprise begins to positive implement and the public starts to choose non-participate behavior, the government will choose negative regulate. The increasing penalties and product revenue under inclusive green effort will promote enterprise to positive implement. Meanwhile, the increase of government subsidies and traditional product price and the decrease of product price under inclusive green effort will promote public to participate.

Let $\mathrm{F}(\mathrm{x})=0, \mathrm{~F}(\mathrm{y})=0, \mathrm{~F}(\mathrm{z})=0$, we can obtain 8 pure strategy solutions of the three dimensional dynamic system, which are $(0,0,0),(0,1,0),(0,0,1),(0,1,1),(1,0,0),(1,0,1),(1,1,0),(1,1$, $1)$, respectively. These eight equilibrium points constitute the boundary of the solutions of the tripartite evolutionary game, which is $\{(x, y, z) \mid 0 \leqslant x \leqslant 1 ; 0 \leqslant y \leqslant 1 ; 0 \leqslant z \leqslant 1\}$. In addition, there exists a mixed strategy solution $\left(x^{*}, y^{*}, z^{*}\right)$.

To summarize this section, the stability of all the equilibrium points in three-dimensional dynamic system are analyzed, and their stability are judged by Lyapunov's method. The system realizes ESS requests all the eigenvalues of Jacobian matrix have negative real parts (Friedman, 1991).

$$
\mathrm{J}_{2}=\left[\begin{array}{lll}
\partial \mathrm{F}(\mathrm{x}) / \partial \mathrm{x} & \partial \mathrm{F}(\mathrm{x}) / \partial \mathrm{y} & \partial \mathrm{F}(\mathrm{x}) / \partial \mathrm{z} \\
\partial \mathrm{F}(\mathrm{y}) / \partial \mathrm{x} & \partial \mathrm{F}(\mathrm{y}) / \partial \mathrm{y} & \partial \mathrm{F}(\mathrm{y}) / \partial \mathrm{z} \\
\partial \mathrm{F}(\mathrm{z}) / \partial \mathrm{x} & \partial \mathrm{F}(\mathrm{z}) / \partial \mathrm{y} & \partial \mathrm{F}(\mathrm{z}) / \partial \mathrm{z}
\end{array}\right]
$$

After calculation, mixed strategy can be proved not an ESS because that its eigenvalues simultaneous have negative real parts cannot be guaranteed. Thus, the eight equilibrium points (pure strategy solutions) are taken into Jacobian matrix, and the eigenvalues of each equilibrium point are 
obtained sequentially, only $(0,0,1)$ and $(1,1,0)$ are instability points, then the conditions of possible equilibrium points are judged as shown in Table 4.

Table 4 The Condition of Evolutionary Stability of Possible Equilibrium Points

\begin{tabular}{|c|c|c|}
\hline $\begin{array}{c}\text { Equilibrium } \\
\text { Points }\end{array}$ & Jacobian Matrix Eigenvalue of $\mathrm{J}_{2}$ & Condition \\
\hline \multirow{3}{*}{$(0,0,0)$} & $\mathrm{F}_{\mathrm{E}}-\mathrm{C}_{\mathrm{L}}$ & $\mathrm{F}_{\mathrm{E}}<\mathrm{C}_{\mathrm{L}}$ \\
\hline & $\mathrm{B}_{\mathrm{E}} * \beta-\mathrm{P}_{\mathrm{N}} * \mathrm{Q}_{\mathrm{N}}+\mathrm{N}$ & $\mathrm{B}_{\mathrm{E}}+\mathrm{N}<\mathrm{P}_{\mathrm{N}} * \mathrm{Q}_{\mathrm{N}}$ \\
\hline & $\mathrm{M}_{2}-\mathrm{C}_{\mathrm{S}}-\mathrm{C}_{\mathrm{P}}+\mathrm{U}_{\mathrm{P}}+\mathrm{P}_{\mathrm{N}} * \mathrm{Q}_{\mathrm{N}}-\mathrm{P}_{\mathrm{i}} * \mathrm{Q}_{\mathrm{i}}$ & $\mathrm{M}_{2}+\mathrm{U}_{\mathrm{P}}+\mathrm{P}_{\mathrm{N}} * \mathrm{Q}_{\mathrm{N}}<\mathrm{P}_{\mathrm{i}} * \mathrm{Q}_{\mathrm{i}}+\mathrm{C}_{\mathrm{S}}+\mathrm{C}_{\mathrm{P}}$ \\
\hline \multirow{3}{*}{$(0,0,1)$} & $\mathrm{E}_{\mathrm{L}}-\mathrm{C}_{\mathrm{L}}+\mathrm{F}_{\mathrm{E}}-\mathrm{M}_{1}+\mathrm{M}_{2}$ & \\
\hline & $\mathrm{R}_{\mathrm{E}}+\mathrm{P}_{\mathrm{i}} * \mathrm{Q}_{\mathrm{i}}+\mathrm{B}_{\mathrm{E}} * \beta+\mathrm{N}$ & Instability point \\
\hline & $\mathrm{C}_{\mathrm{P}}+\mathrm{C}_{\mathrm{S}}-\mathrm{M}_{2}-\mathrm{U}_{\mathrm{P}}-\mathrm{P}_{\mathrm{N}} * \mathrm{Q}_{\mathrm{N}}+\mathrm{P}_{\mathrm{i}} * \mathrm{Q}_{\mathrm{i}}$ & \\
\hline \multirow{3}{*}{$(0,1,0)$} & $-\mathrm{C}_{\mathrm{L}}$ & \\
\hline & $\mathrm{P}_{\mathrm{N}} * \mathrm{Q}_{\mathrm{N}}-\mathrm{B}_{\mathrm{E}}-\mathrm{N}$ & $\mathrm{P}_{\mathrm{N}} * \mathrm{Q}_{\mathrm{N}}<\mathrm{B}_{\mathrm{E}}+\mathrm{N}$ \\
\hline & $\mathrm{M}_{2}-\mathrm{C}_{\mathrm{P}}+\mathrm{U}_{\mathrm{P}}+\mathrm{P}_{\mathrm{N}} * \mathrm{Q}_{\mathrm{N}}-\mathrm{P}_{\mathrm{i}} * \mathrm{Q}_{\mathrm{i}}$ & $\mathrm{M}_{2}+\mathrm{U}_{\mathrm{P}}+\mathrm{P}_{\mathrm{N}} * \mathrm{Q}_{\mathrm{N}}<\mathrm{P}_{\mathrm{i}} * \mathrm{Q}_{\mathrm{i}}+\mathrm{C}_{\mathrm{P}}$ \\
\hline \multirow{3}{*}{$(0,1,1)$} & $\mathrm{E}_{\mathrm{L}}-\mathrm{C}_{\mathrm{L}}-\mathrm{M}_{1}+\mathrm{M}_{2}$ & \\
\hline & $-\mathrm{R}_{\mathrm{E}}-\mathrm{P}_{\mathrm{i}} * \mathrm{Q}_{\mathrm{i}}-\mathrm{B}_{\mathrm{E}}-\mathrm{N}$ & $\mathrm{E}_{\mathrm{L}}+\mathrm{M}_{2}<\mathrm{C}_{\mathrm{L}}+\mathrm{M}_{1}$ \\
\hline & $\mathrm{C}_{\mathrm{P}}-\mathrm{M}_{2}-\mathrm{U}_{\mathrm{P}}-\mathrm{P}_{\mathrm{N}} * \mathrm{Q}_{\mathrm{N}}+\mathrm{P}_{\mathrm{i}} * \mathrm{Q}_{\mathrm{i}}$ & $\mathrm{C}_{\mathrm{P}}+\mathrm{P}_{\mathrm{i}} * \mathrm{Q}_{\mathrm{i}}<\mathrm{M}_{2}+\mathrm{U}_{\mathrm{P}}+\mathrm{P}_{\mathrm{N}} * \mathrm{Q}_{\mathrm{N}}$ \\
\hline \multirow{3}{*}{$(1,0,0)$} & $\mathrm{C}_{\mathrm{L}}-\mathrm{F}_{\mathrm{E}}$ & $\mathrm{C}_{\mathrm{L}}<\mathrm{F}_{\mathrm{E}}$ \\
\hline & $\mathrm{F}_{\mathrm{E}}-\mathrm{C}_{\mathrm{E}}+\mathrm{R}_{\mathrm{E}}-\mathrm{P}_{\mathrm{N}} * \mathrm{Q}_{\mathrm{N}}+\mathrm{B}_{\mathrm{E}}+\mathrm{N}$ & $\mathrm{F}_{\mathrm{E}}+\mathrm{R}_{\mathrm{E}}+\mathrm{B}_{\mathrm{E}}+\mathrm{N}<\mathrm{C}_{\mathrm{E}}+\mathrm{P}_{\mathrm{N}} * \mathrm{Q}_{\mathrm{N}}$ \\
\hline & $\mathrm{M}_{1}-\mathrm{C}_{\mathrm{S}}-\mathrm{C}_{\mathrm{P}}+\mathrm{U}_{\mathrm{P}}+\mathrm{P}_{\mathrm{N}} * \mathrm{Q}_{\mathrm{N}}-\mathrm{P}_{\mathrm{i}} * \mathrm{Q}_{\mathrm{i}}$ & $\mathrm{M}_{1}+\mathrm{P}_{\mathrm{N}} * \mathrm{Q}_{\mathrm{N}}+\mathrm{U}_{\mathrm{P}}<\mathrm{C}_{\mathrm{S}}+\mathrm{C}_{\mathrm{P}}+\mathrm{P}_{\mathrm{i}}{ }^{*} \mathrm{Q}_{\mathrm{i}}$ \\
\hline \multirow{3}{*}{$(1,0,1)$} & $\mathrm{C}_{\mathrm{L}}-\mathrm{E}_{\mathrm{L}}-\mathrm{F}_{\mathrm{E}}+\mathrm{M}_{1}-\mathrm{M}_{2}$ & $\mathrm{C}_{\mathrm{L}}+\mathrm{M}_{1}<\mathrm{M}_{2}+\mathrm{E}_{\mathrm{L}}+\mathrm{F}_{\mathrm{E}}$ \\
\hline & $\mathrm{F}_{\mathrm{E}}-\mathrm{C}_{\mathrm{E}}+\mathrm{R}_{\mathrm{E}}+\mathrm{P}_{\mathrm{i}} * \mathrm{Q}_{\mathrm{i}}+\mathrm{B}_{\mathrm{E}}+\mathrm{N}$ & $\mathrm{F}_{\mathrm{E}}+\mathrm{R}_{\mathrm{E}}+\mathrm{P}_{\mathrm{i}} * \mathrm{Q}_{\mathrm{i}}+\mathrm{B}_{\mathrm{E}}+\mathrm{N}<\mathrm{C}_{\mathrm{E}}$ \\
\hline & $\mathrm{C}_{\mathrm{P}}+\mathrm{C}_{\mathrm{S}}-\mathrm{M}_{1}-\mathrm{U}_{\mathrm{P}}-\mathrm{P}_{\mathrm{N}} * \mathrm{Q}_{\mathrm{N}}+\mathrm{P}_{\mathrm{i}} * \mathrm{Q}_{\mathrm{i}}$ & $\mathrm{C}_{\mathrm{P}}+\mathrm{C}_{\mathrm{S}}+\mathrm{P}_{\mathrm{i}} * \mathrm{Q}_{\mathrm{i}}<\mathrm{M}_{1}+\mathrm{U}_{\mathrm{P}}+\mathrm{P}_{\mathrm{N}} * \mathrm{Q}_{\mathrm{N}}$ \\
\hline \multirow{3}{*}{$(1,1,0)$} & $\mathrm{C}_{\mathrm{L}}$ & \\
\hline & $\mathrm{C}_{\mathrm{E}}-\mathrm{F}_{\mathrm{E}}-\mathrm{R}_{\mathrm{E}}+\mathrm{P}_{\mathrm{N}} * \mathrm{Q}_{\mathrm{N}}-\mathrm{BE}-\mathrm{N}$ & Instability point \\
\hline & $\mathrm{M}_{1}-\mathrm{C}_{\mathrm{P}}+\mathrm{U}_{\mathrm{P}}+\mathrm{P}_{\mathrm{N}} * \mathrm{Q}_{\mathrm{N}}-\mathrm{P}_{\mathrm{i}} * \mathrm{Q}_{\mathrm{i}}$ & \\
\hline \multirow{3}{*}{$(1,1,1)$} & $\mathrm{C}_{\mathrm{L}}-\mathrm{E}_{\mathrm{L}}+\mathrm{M}_{1}-\mathrm{M}_{2}$ & $\mathrm{C}_{\mathrm{L}}+\mathrm{M}_{1}<\mathrm{E}_{\mathrm{L}}+\mathrm{M}_{2}$ \\
\hline & $\mathrm{C}_{\mathrm{E}}-\mathrm{F}_{\mathrm{E}}-\mathrm{R}_{\mathrm{E}}-\mathrm{P}_{\mathrm{i}} * \mathrm{Q}_{\mathrm{i}}-\mathrm{B}_{\mathrm{E}}-\mathrm{N}$ & $\mathrm{C}_{\mathrm{E}}<\mathrm{F}_{\mathrm{E}}+\mathrm{R}_{\mathrm{E}}+\mathrm{P}_{\mathrm{i}} * \mathrm{Q}_{\mathrm{i}}+\mathrm{B}_{\mathrm{E}}+\mathrm{N}$ \\
\hline & $\mathrm{C}_{\mathrm{P}}-\mathrm{M}_{1}-\mathrm{U}_{\mathrm{P}}-\mathrm{P}_{\mathrm{N}} * \mathrm{Q}_{\mathrm{N}}+\mathrm{P}_{\mathrm{i}} * \mathrm{Q}_{\mathrm{i}}$ & $\mathrm{C}_{\mathrm{P}}+\mathrm{P}_{\mathrm{i}} * \mathrm{Q}_{\mathrm{i}}<\mathrm{M}_{1}+\mathrm{U}_{\mathrm{P}}+\mathrm{P}_{\mathrm{N}} * \mathrm{Q}_{\mathrm{N}}$ \\
\hline
\end{tabular}

Limited by length, we cannot analyze all the local stabilities of each equilibrium point. According to the characteristics of regional development, this paper selects ESS in the typical stage of inclusive green growth as can be seen in Table 5 .

Table 5 The three stages of inclusive green growth

\begin{tabular}{|c|c|c|}
\hline Stage & Equilibrium Points & Condition \\
\hline Initial & $(1,0)(0,0,0)$ & $\begin{array}{c}\mathrm{C}_{\mathrm{C}}<\mathrm{F}_{\mathrm{L}}<\mathrm{C}_{\mathrm{L}}+\mathrm{L}_{\mathrm{L}} * \gamma_{\mathrm{e}}-\mathrm{R}_{\mathrm{L}} *\left(\gamma_{\mathrm{g}}+\gamma_{\mathrm{i}}\right) \\
\mathrm{F}_{\mathrm{E}}<\mathrm{C}_{\mathrm{L}} ; \mathrm{B}_{\mathrm{E}}+\mathrm{N}<\mathrm{P}_{\mathrm{N}} * \mathrm{Q}_{\mathrm{N}}<\mathrm{P}_{\mathrm{i}} * \mathrm{Q}_{\mathrm{i}}+\mathrm{C}_{\mathrm{S}}+\mathrm{C}_{\mathrm{P}}-\mathrm{M}_{2}-\mathrm{U}_{\mathrm{P}}\end{array}$ \\
\hline Middle & $(0,1)(1,1,1)$ & $\begin{array}{c}\mathrm{C}_{\mathrm{L}}+\mathrm{L}_{\mathrm{L}} * \gamma_{\mathrm{e}}<\mathrm{R}_{\mathrm{L}} *\left(\gamma_{\mathrm{g}}+\gamma_{\mathrm{i}}\right) ; \mathrm{C}_{\mathrm{L}}+\mathrm{M}_{1}<\mathrm{E}_{\mathrm{L}}+\mathrm{M}_{2} ; \\
\mathrm{C}_{\mathrm{E}}-\mathrm{F}_{\mathrm{E}}-\mathrm{R}_{\mathrm{E}}-\mathrm{B}_{\mathrm{E}}-\mathrm{N}<\mathrm{P}_{\mathrm{i}} * \mathrm{Q}_{\mathrm{i}}<\mathrm{M}_{1}+\mathrm{U}_{\mathrm{P}}+\mathrm{P}_{\mathrm{N}} * \mathrm{Q}_{\mathrm{N}}-\mathrm{C}_{\mathrm{P}}\end{array}$ \\
\hline Mature & $(0,0)(0,1,1)$ & $\begin{array}{c}\mathrm{C}_{\mathrm{L}}+\mathrm{L}_{\mathrm{L}} * \gamma_{\mathrm{e}}>\mathrm{R}_{\mathrm{L}} *\left(\gamma_{\mathrm{g}}+\gamma_{\mathrm{i}}\right) ; \mathrm{C}_{\mathrm{C}}>\mathrm{F}_{\mathrm{L}} \\
\mathrm{C}_{\mathrm{P}}+\mathrm{P}_{\mathrm{i}} * \mathrm{Q}_{\mathrm{i}}-\mathrm{U}_{\mathrm{P}}-\mathrm{P}_{\mathrm{N}} * \mathrm{Q}_{\mathrm{N}}<\mathrm{M}_{2}<\mathrm{C}_{\mathrm{L}}+\mathrm{M}_{1}-\mathrm{E}_{\mathrm{L}}\end{array}$ \\
\hline
\end{tabular}


In the initial stage of IGG, the penalty on local government is lower than central government's positive supervision cost, but higher than local government's cost of positive regulation. Besides, the traditional product revenue is between the benefits of enterprise and public's positive behaviors. Therefore, the central government positively strengthens the supervision over the local government, while the local government, enterprise and public choose negative participate behaviors. Thus, this stage corresponds to the ESS $(1,0)$ and $(0,0,0)$. As can be seen from the Table 3 , Table 4 , in the initial stage of IGG, four inequalities should be met to realize optimal ESS $(1,0)$ and $(0,0,0)$.

In the middle stage of IGG, the benefits of local government's positive regulation are higher than the cost of its positive regulation, and the product revenue under inclusive green effort is between the enterprise's negative implementation cost and public's positive participation benefits. Therefore, as the proportion of environmental protection and income inequity reduction in the assessment increase, and the product revenue under inclusive green effort decreases, the local government, enterprise and public will begin to choose positive behaviors. This stage corresponds to the ESS (0, $1)$ and $(1,1,1)$.

As in the mature stage, the penalty on local government is lower than central government's positive supervision cost, and the subsidies to the public are between the cost of public's positive participation and local government's positive regulation. In this stage, the governments will slowly withdraw from IGG, and the enterprise and public will take the initiative to implement positive behavior without governments' supervision, resulting in the $\operatorname{ESS}(0,0)$ and $(0,1,1)$.

\section{Numerical simulation}

In China, the central government is appealing the stakeholders to positively participate to promote the economy booming, improve environmental quality and reduce income inequality. In order to intuitively describe the dynamic evolution of stakeholders in the inclusive green growth, numerical simulations are introduced to the above optimal evolutionary stability strategy in the typical stages. On the basis of the situation in China, the Sections 4.1, 4.2 analyze the strategic behaviors of the stakeholders, and clarify the impact of parameters on their strategic behaviors.

\subsection{Strategic analysis}

To clarify the impact of variables on stakeholders' strategic behaviors, we introduce the numerical simulation to analyze the dynamic process for the evolutionary systems. We set the strategy probabilities of all stakeholders as 0.5 . Then take the initial stage as an example, the parameters are set as follows: $C_{C}=5, R_{L}=20, F_{L}=20, L_{L}=15, C_{L}=30, \gamma_{i}=0.2, \gamma_{g}=0.2, \gamma_{e}=0.6$. And $B_{L}=1, M_{1}=21$, $\mathrm{M}_{2}=20, \mathrm{~B}_{\mathrm{E}}=0.8, \mathrm{C}_{\mathrm{E}}=30, \mathrm{U}_{\mathrm{P}}=5, \mathrm{C}_{\mathrm{P}}=25, \mathrm{C}_{\mathrm{L}}=30, \mathrm{R}_{\mathrm{E}}=1, \mathrm{C}_{\mathrm{S}}=25, \mathrm{R}_{\mathrm{P}}=3, \mathrm{~F}_{\mathrm{E}}=1, \mathrm{~N}=0.6, \mathrm{P}_{\mathrm{i}}=6, \mathrm{Q}_{\mathrm{i}}=1, \mathrm{P}_{\mathrm{N}}=4$, $\mathrm{Q}_{\mathrm{N}}=7, \mathrm{E}_{\mathrm{P}}=3, \mathrm{E}_{\mathrm{L}}=31$.

The ESS of each stage in IGG is as shown in the Fig 2.1 and Fig 2.2. In the initial stage, the local government, and enterprise reach the equilibrium point fast, while the central government slowly chooses the positive supervise behavior. In the middle stage, the governments and enterprise reach the equilibrium point early, though the public chooses the positive participate behavior in the last. As can be seen, in the mature stage, the central government and public take a longer time to choose negative supervision and positive participate behavior.

Therefore, the local government reaches the equilibrium at the quickest speed in both models, and the evolutionary speed of public is slowest. Hence, the local government should play a leading role in promoting IGG. 


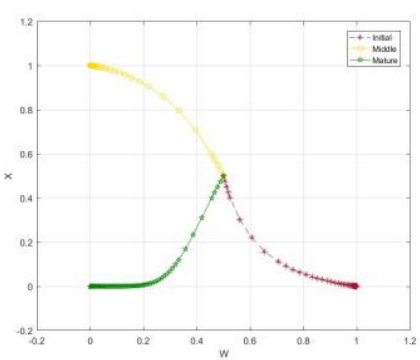

Fig 2.1 Three stages of ESS in central supervision

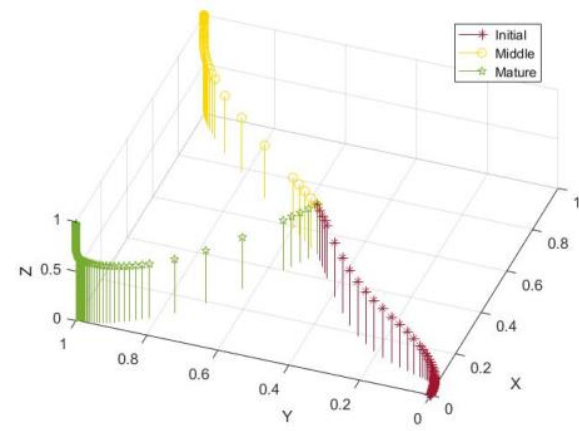

Fig 2.2 Three stages of ESS in local regulation

\subsection{Sensitivity analysis}

In order to further analyze the impacts of main parameters' changes on the strategic behaviors of the stakeholders, sensitivity analysis is performed through numerical simulations. Thus, as shown in Fig 3.1 and Fig 3.2, the numerical simulations for the penalty on local government $F_{L}$, economy proportion in assessment $\gamma_{e}$, product price under inclusive green effort $P_{i}$, penalty on enterprise $F_{E}$, public's monitoring cost $\mathrm{C}_{\mathrm{S}}$, respectively.
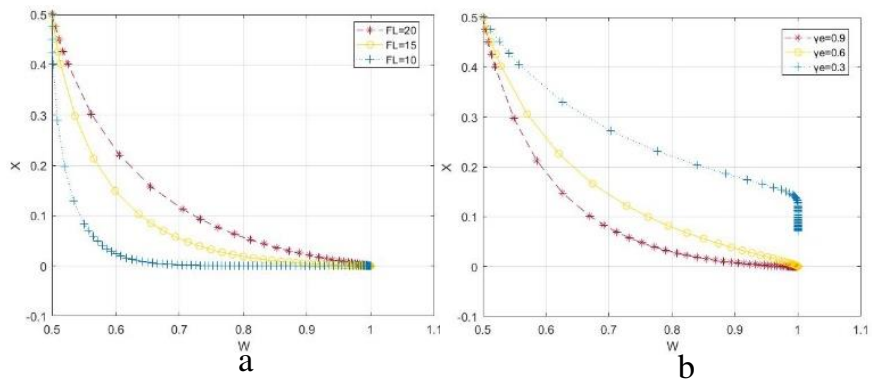

Fig 3.1 The sensitivity analysis in central supervision

As shown in Fig 3.1, in the central and local government game model, the values of $F_{L}$ are set as 10 , 15 , and 20, and $\gamma_{\mathrm{e}}$ are set as $0.3,0.6$, and 0.9 . The decrease of $F_{L}$ will result in a dual decreases of both $\mathrm{x}$ and $\mathrm{w}$, while $\mathrm{x}$ decreases faster. This indicates that as the penalty on local government decreases, the central government and local government's enthusiasm will both be reduced, and local government is more sensitive to this decrease. Besides, when $\gamma_{\mathrm{e}}$ decreases, w quickly stabilizes at 1 , and $x$ takes a longer time to reach 0 . Thus, the decrease of the economic proportion in the assessment will significantly promote central and local governments' willingness to participate, and 
it has a greater impact on local government. In conclusion, the penalty on local government and the economy proportion in assessment both have a positive impact on promoting central and local government to participate in IGG, and local government is more sensitive to the changes of these parameters.

The sensitivity analysis in local government and enterprise and public model is as can be seen in Fig 3.2. As for product price of from enterprises' inclusive green effort, the values of $P_{i}$ are set as 4 , 5 and $6 . F_{E}$ are set as $26,29,32$, and $C_{S}$ are set as 20, 25 and 30 . When $P_{\mathrm{i}}$ increases, $y$ takes a longer time to reach equilibrium point 0 , while $\mathrm{z}$ reaches faster and its equilibrium point has changed from 1 to 0 . The increase of $\mathrm{F}_{\mathrm{E}}$ shortens time for $\mathrm{y}$ and $\mathrm{z}$ to reach equilibrium point, and $\mathrm{x}$ gradually stabilized at 1 . As $\mathrm{C}_{\mathrm{S}}$ increases, it can be found that $\mathrm{y}$ finally stabilizes at 0 . In summary, the results show that the increasing product price under inclusive green effort will promote the enterprise's enthusiasm for positively implement in IGG, but also hinders the public's participation willingness. The increase of penalty on enterprise will promote both enterprise and public to positively participate, while the increase of public monitoring cost hinders them both. Meanwhile, all these three parameters have little impact on local government's strategies.
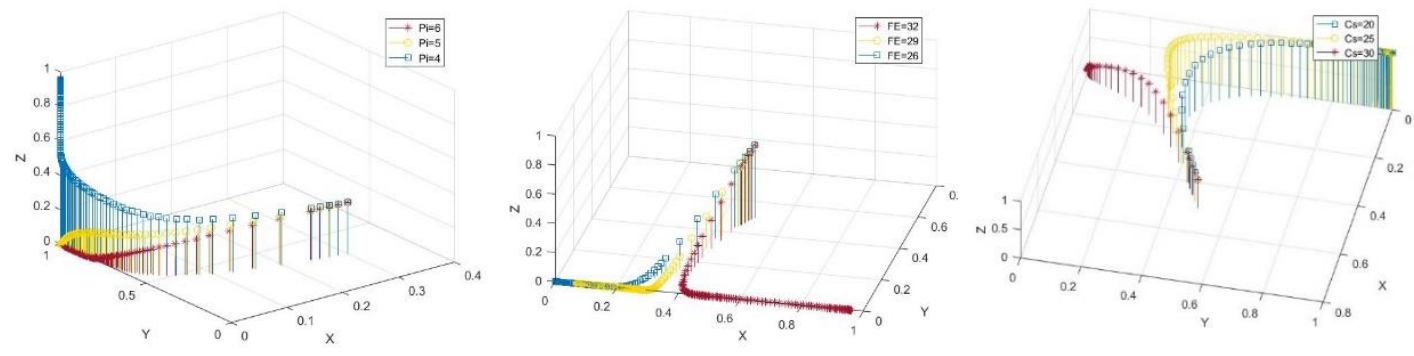

Fig 3.2 The sensitivity analysis in local regulation

\section{Conclusion and policy implications}

\subsection{Conclusions}

The achievement of IGG has a great significance for China's further sustainable development. In order to improve IGG degree and enhance the stakeholders' enthusiasm to participate, this paper established an evolutionary game model between central and local government and a model among local government and enterprise and public, and analyzed how to promote the stakeholders' participations under central supervision and local regulation in IGG. Numerical simulations were conducted to investigate the impacts of relevant parameters on the stakeholders' strategic behaviors. These findings can help policy-makers in China to improve their guide planning, and the model may also be replicated in other developing countries to obtain IGG by promoting economic growth, environmental protection and income inequity reduction. After analysis, the following conclusions are drawn:

(1) In the initial stage, the proportion of economic output in the assessment, should be reduced to promote the local government to positively regulate, and the product revenue under enterprises' positive inclusive green effort and the cost for the public to participate should be reduced to promote enterprise and public to positively participate in IGG. What's more, the product revenue under inclusive green effort should be kept between the cost of enterprise's positive implementation and the benefits of the public's positive participation.

In the middle stage, the subsidies for the public should be kept between the cost of public and local 
government to transit to the mature stage.

In the mature stage, the governments gradually relax the supervision and regulation, the enterprise and the public become the main force for IGG.

(2) Among the stakeholders, the local government reaches equilibrium at a fastest speed, and the public is the latest to reach equilibrium point, therefore local government should play a leading role. In the central and local game model, increasing the penalty on local government and decreasing economic proportion in assessment have a greater impact on promoting local government's regulation. In the local and enterprise and public game model, when the product price under enterprises' inclusive green effort increases, the enthusiasm of enterprise increases, while the enthusiasm of deceases. The increase of penalty on enterprise will improve the enterprise and public's willingness to participate, though the increase of public's monitoring cost will reduce the enterprise and public's willingness.

\subsection{Policy implications}

Based on the above analysis suggested, some implications are put forward as follows:

As the major driving force in the initial stage, central government should further improve the assessment on local government. It is crucial to strictly refine the local government's accountability in environmental protection and income inequity reduction, and enhance the local government's political benefits for environmental protection and income inequity reduction. Besides, fiscal policies should be rational formulated to reduce local government's regulate cost, such as financial subsidies and special funds for income inequity reduction and environmental protection. Meanwhile, subsidies for technological innovation and inclusive green production should be set to promote enterprises' enthusiasm.

Strictly supervision and official certification should be conducted to the enterprises' behavior on environmental protection and income inequity reduction, to enhance their technological innovation and social reputation.

The public should be particularly encouraged to participate in IGG. Public supervision platform, subsidy mechanism and policy advocacy should be conducted via the Internet and public media, in order to reduce their monitoring cost and public awareness on IGG.

In this paper, model analysis and numerical simulation were used to investigate IGG, the strategies of the stakeholders are analyzed. However, how to balance the cost of enterprises' environmental protection and the cost of income inequity reduction is not involved. Thus, we expect the relationship between these costs was found in further researches.

\section{Declarations}

- Ethics approval and consent to participate Not applicable.

- Consent for publication Not applicable.

- Availability of data and materials

The datasets used or analysed during the current study are available from the corresponding author on reasonable request.

- Competing interests

The authors have declared that no competing interests exist.

- Funding 
This study is supported by the National Natural Science Foundation of China (72004019, 71974028), and National Social Science Fund of China (Grant Number: 18BGL153).

- Authors' contributions

Ying Qu: Supervision; Yaodong Cang: Conceptualization, Methodology, Software, Data curation and Writing- Original draft; Lingling Guo: Reviewing and Editing; Yue Liu: constructive discussions.

The authors declare that there is no conflict of interests regarding the publication of this article.

- Authors' information (optional)

The authors are from Dalian University of echnology and Nanjing Forestry University.

Acknowledgement:

This study is supported by the National Natural Science Foundation of China (72004019, 71974028), and National Social Science Fund of China (18BGL153)

\section{References}

Albagoury, S. (2016). Inclusive Green Growth in Africa: Ethiopia Case Study. MPRA Paper

Berkhout, E.Bouma, J.Terzidis, N., \&Voors, M. (2018). Supporting local institutions for inclusive green growth: Developing an Evidence Gap Map. NJAS - Wageningen Journal of Life Sciences, 84(51-71. https://doi.org/10.1016/j.njas.2017.10.001

Cai, W., \&Ye, P. (2020). How does environmental regulation influence enterprises' total factor productivity? A quasi-natural experiment based on China' s new environmental protection law. Journal of Cleaner Production, 276(124105. https://doi.org/10.1016/j.jclepro.2020.124105

Coughlan SLehmann F, \&Lehmann J P. (2009). Inclusive growth: The road for global prosperity and stability. In:The ICC CEO Regional Forum.

Cui, H.Wang, R., \&Wang, H. (2020). An evolutionary analysis of green finance sustainability based on multi-agent game. Journal of Cleaner Production, 269(121799. https://doi.org/10.1016/j.jclepro.2020.121799

D. Friedman. (1991). Evolutionary games in economics. Econometrica, 59(3), 637-666

Dai, X., \&Li, J. (2021). Inequality of opportunity in China: Evidence from pseudo panel data. China Economic Review, 101637. https://doi.org/10.1016/j.chieco.2021.101637

Dev S M. (2007). Inclusive Growth in Andhra Pradesh:Challenges in Agriculture, Poverty, Social Sector and Regional Disparities. Macroeconomics Working Papers

Dhingra R M. (2015). Inclusive green growth: A key to unlock multi-dimensional problems. In:XVI Annual Conference Proceedings.

Du, L.Feng, Y.Lu, W.Kong, L., \&Yang, Z. (2020). Evolutionary game analysis of stakeholders' decisionmaking behaviours in construction and demolition waste management. Environmental impact assessment review, 84(106408. https://doi.org/10.1016/j.eiar.2020.106408

Fang, Y.Wei, W.Liu, F.Mei, S.Chen, L., \&Li, J. (2019). Improving solar power usage with electric vehicles: Analyzing a public-private partnership cooperation scheme based on evolutionary game theory. Journal of Cleaner Production, 233(1284-1297. https://doi.org/10.1016/j.jclepro.2019.06.001

Friedman, D. (1991). Evolutionary games in economics. Econometrica, 59(3), 637-666

Hanewald, K.Jia, R., \&Liu, Z. (2021). Why is inequality higher among the old? Evidence from China. China Economic Review, 66(101592. https://doi.org/10.1016/j.chieco.2021.101592 
Kolcava, D.Rudolph, L., \&Bernauer, T. (2021). Citizen preferences on private-public co-regulation in environmental governance: Evidence from Switzerland. Global Environmental Change, 68(102226. https://doi.org/10.1016/j.gloenvcha.2021.102226

Liao, X., \&Shi, X. R. (2018). Public appeal, environmental regulation and green investment: Evidence from China. Energy Policy, 119(554-562. https://doi.org/10.1016/j.enpol.2018.05.020

Liu, K., \&Lin, B. (2019). Research on influencing factors of environmental pollution in China: A spatial econometric analysis. Journal of Cleaner Production, 206(356-364. https://doi.org/10.1016/j.jclepro.2018.09.194

Meyer, B.Meyer, M., \&Distelkamp, M. (2012). Modeling green growth and resource efficiency: new results. Mineral Economics, 24(2-3), 145-154. https://doi.org/10.1007/s13563-011-0008-3

OECD. (2009). Declaration on green growth. Available

Ojha, V. P.Pohit, S., \&Ghosh, J. (2020). Recycling carbon tax for inclusive green growth: A CGE analysis of India. Energy Policy, 144(111708. https://doi.org/10.1016/j.enpol.2020.111708

Pan, W.Pan, W.Hu, C.Tu, H.Zhao, C.Yu, D.Xiong, J., \&Zheng, G. (2019). Assessing the green economy in China: An improved framework. Journal of Cleaner Production, 209(680-691. https://doi.org/10.1016/j.jclepro.2018.10.267

Peng, J.Xie, R.Ma, C., \&Fu, Y. (2021). Market-based environmental regulation and total factor productivity: Evidence from Chinese enterprises. Economic Modelling, 95(394-407. https://doi.org/10.1016/j.econmod.2020.03.006

Qiao, W., \&Yin, X. (2021). Understanding the impact on energy transition of consumer behavior and enterprise decisions through evolutionary game analysis. Sustainable Production and Consumption, 28(231-240. https://doi.org/10.1016/j.spc.2021.04.015

Reilly, J. M. (2012). Green growth and the efficient use of natural resources. Energy Economics, 34(S85S93. https://doi.org/10.1016/j.eneco.2012.08.033

Sheng, J.Zhou, W., \&Zhu, B. (2020). The coordination of stakeholder interests in environmental regulation: Lessons from China' s environmental regulation policies from the perspective of the evolutionary game theory. Journal of Cleaner Production, 249(119385. https://doi.org/10.1016/j.jclepro.2019.119385

Smith, J. M. (1974). The theory of games and the evolution of animal conflicts. Journal of Theoretical Biology, 47(1), 209-221

Song, H.Zhao, C., \&Zeng, J. (2017). Can environmental management improve financial performance: An empirical study of A-shares listed companies in China. Journal of Cleaner Production, 141(10511056. https://doi.org/10.1016/j.jclepro.2016.09.105

Sun, H.Wan, Y.Zhang, L., \&Zhou, Z. (2019). Evolutionary game of the green investment in a twoechelon supply chain under a government subsidy mechanism. Journal of Cleaner Production, 235(1315-1326. https://doi.org/10.1016/j.jclepro.2019.06.329

Sun, H., \&Li, J. (2021). Behavioural choice of governments, enterprises and consumers on recyclable green logistics packaging. Sustainable Production and Consumption, 28(459-471. https://doi.org/10.1016/j.spc.2021.06.011

Sun, X.Wang, W.Pang, J.Liu, X., \&Zhang, M. (2021). Study on the evolutionary game of central government and local governments under central environmental supervision system. Journal of Cleaner Production, 296(126574. https://doi.org/10.1016/j.jclepro.2021.126574

Sun, Y.Ding, W.Yang, Z.Yang, G., \&Du, J. (2020a). Measuring China's regional inclusive green growth. Science of The Total Environment, 713(136367. https://doi.org/10.1016/j.scitotenv.2019.136367 
Sun, Y.Ding, W.Yang, Z.Yang, G., \&Du, J. (2020b). Measuring China's regional inclusive green growth. Science of The Total Environment, 713(136367. https://doi.org/10.1016/j.scitotenv.2019.136367

Tang, H.Liu, J., \&Wu, J. (2020). The impact of command-and-control environmental regulation on enterprise total factor productivity: A quasi-natural experiment based on China's "Two Control Zone policy. Journal of Cleaner Production, 254(120011. https://doi.org/10.1016/j.jclepro.2020.120011

Tang, P.Feng, Y.Li, M., \&Zhang, Y. (2021). Can the performance evaluation change from central government suppress illegal land use in local governments? A new interpretation of Chinese decentralisation. Land Use Policy, 108(105578. https://doi.org/10.1016/j.landusepol.2021.105578

Tian, Y.Govindan, K., \&Qinghua Zhu. (2014). A system dynamics model based on evolutionary game theory for green supply chain management diffusion among Chinese manufacturers. Journal of cleaner production, 80(Oct.1), 96-105. https://doi.org/10.1016/j.jclepro.2014.05.076

UNESCAP. (2005). Shifting towards “Green Growth" in Asia and the Pacific. Available

Wang, C.Chu, Z., \&Gu, W. (2021). Assessing the role of public attention in China's wastewater treatment: A spatial perspective. Technological Forecasting and Social Change, 171(120984. https://doi.org/10.1016/j.techfore.2021.120984

Wang, L.Zhao, N., \&Liu, D. (2020). Complex disaster management: A dynamic game among the government, enterprises, and residents. Journal of Cleaner Production, 266(122091. https://doi.org/10.1016/j.jclepro.2020.122091

Wang, M. Y.Li, Y.Cheng, Z.Zhong, C., \&Ma, W. (2021). Evolution and equilibrium of a green technological innovation system: Simulation of a tripartite game model. Journal of Cleaner Production, 278(123944. https://doi.org/10.1016/j.jclepro.2020.123944

Wang, W.Sun, X., \&Zhang, M. (2021). Does the central environmental inspection effectively improve air pollution?-An empirical study of 290 prefecture-level cities in China. Journal of Environmental Management, 286(112274. https://doi.org/10.1016/j.jenvman.2021.112274

WB. (2012). Inclusive green growth: The pathway to sustainable development) Washington: World Bank Publications.

World Bank. (2006). World development report 2006:Equity and Development. Available

World Bank. (2012). The Pathway to Sustainable DevelopmentWorld Bank Publication.

Xiang, C., \&van Gevelt, T. (2020). Central inspection teams and the enforcement of environmental regulations in China. Environmental Science \& Policy, 112(431-439. https://doi.org/10.1016/j.envsci.2020.06.018

Xiaoliang, Z., \&Wulin, W. (2018). The Measurement and Analysis of the Inclusive Green Growth in China. The Journal of Quantitative \& Technical Economics, 35(08), 3-20

Xu, L.Zhang, Q., \&Shi, X. (2019). Stakeholders strategies in poverty alleviation and clean energy access: A case study of China's PV poverty alleviation program. Energy Policy, 135(111011. https://doi.org/10.1016/j.enpol.2019.111011

Yao, X.Zhang, X., \&Guo, Z. (2020). The tug of war between local government and enterprises in reducing China's carbon dioxide emissions intensity. Science of The Total Environment, 710(136140. https://doi.org/10.1016/j.scitotenv.2019.136140

Yu, X., \&Wang, H. (2013). How should the center lead China's reforestation efforts?-Policy making games between central and local governments. Resources, Conservation and Recycling, 80(64-84. https://doi.org/10.1016/j.resconrec.2013.09.001

Yunan, X.Weixin, L.Yujie, Y., \&Hui, W. (2021). Evolutionary game for the stakeholders in livestock 
pollution control based on circular economy. Journal of Cleaner Production, 282(125403. https://doi.org/10.1016/j.jclepro.2020.125403

Zhang, B.Chen, X., \&Guo, H. (2018). Does central supervision enhance local environmental enforcement? Quasi-experimental evidence from China. Journal of Public Economics, 164(70-90. https://doi.org/10.1016/j.jpubeco.2018.05.009

Zhang, L.Xue, L., \&Zhou, Y. (2019). How do low-carbon policies promote green diffusion among alliance-based firms in China? An evolutionary-game model of complex networks. Journal of Cleaner Production, 210(518-529. https://doi.org/10.1016/j.jclepro.2018.11.028

Zhou, D.Qiu, Y., \&Wang, M. (2021). Does environmental regulation promote enterprise profitability? 